\title{
Cinema Brabantia
}

\author{
Ontstaan en koers van het Brabants Filmarchief
}

\section{Frank van der Maden}

Het Brabants Filmarchief is in eerste instantie opgezet als virtueel archief. Dat wil zeggen: een plek waar gegevens over elders bewaarde films en video's met betrekking tot Noord-Brabant werden verzameld en in een centrale database ondergebracht. Dit uitgangspunt had alles te maken met de activiteiten van de voorganger van het BFA, de Stichting Brabants Filmarchief. Het liep anders. Over de koerswijziging en de gevolgen daarvan voor de audiovisuele archivering in Noord-Brabant gaat deze bijdrage.

In 1992 had J. van Muilekom in het blad Brabantia de alarmbel geluid. Hij stelde 'dat in Noord-Brabant (en daarbuiten) historisch beeldmateriaal van regionaal belang vrijwel vogelvrij is. Een goedwillend lokaal archief wil aangeboden materiaal nog wel eens netjes opbergen, van systematische registratie, ontsluiting en beschikbaarstelling, laat staan van duurzame conservering van vaak kwetsbaar filmmateriaal is nergens sprake. Door geldgebrek, door gebrek aan affiniteit, door onwil."

Op ro november 1995 besloot de Provincie Noord-Brabant aan de Katholieke Universiteit Brabant (кив) extra financiële middelen ter beschikking te stellen om in de periode 1996-1999 een structurele beheersvorm voor films over Noord-Brabant op te bouwen. Hiervoor werd als onderdeel van de bij de кUв-bibliotheek ondergebrachte Brabant-Collectie het Brabants Film Archief (BFA) in het leven geroepen, een plek waar gegevens over elders bewaarde films en video's met betrekking tot NoordBrabant werden verzameld en in een centrale database ondergebracht. In tegenstelling tot andere regionale audiovisuele archieven was het niet de bedoeling om het oorspronkelijke film- en videomateriaal te acquireren.

De Stichting Brabants Filmarchief stelde zich ten doel in elk geval te registreren waar film- en videomateriaal over Noord-Brabant werd bewaard. In de periode 1992-1995 verzamelden de medewerkers van deze stichting gegevens van enkele duizenden films en filmfragmenten. Een groot deel van dit materiaal werd overigens niet in Noord-Brabant bewaard, maar maakte deel uit van de collectie van het Avac (Audiovisueel Archief Centrum), beter bekend als het Omroeparchief, in Hilversum (nu 
het Nederlands Audiovisueel Archief). Het voornemen om al deze gegevens onder te brengen in een centrale filmdatabank kon echter niet ten uitvoer worden gebracht, omdat de stichting daartoe de financiële middelen ontbraken. Zo bestond de boedel van de stichting medio 1995 uit niet veel meer dan een tiental floppy's en acht ordners met, gedigitaliseerd en/of in print, de catalogi van enkele tientallen av-archiefbeherende personen en instellingen. Toch was dit een belangrijk resultaat, vooral omdat het overtuigend aantoonde dat een structurele oplossing dringend gewenst was.

\section{Structurele beheersvorm}

Het was de bibliotheek van de кив die het estafettestokje overnam. In september 1995 zag een beleidsnotitie het licht: Naar een structurele beheersvorm voor het documentaire bewegend beeld over Noord-Brabant. Daarin stelde de bibliotheek zich de volgende doelen:

$I$ het opsporen, selecteren en ontsluiten van documentaire films en videobanden over Noord-Brabant alsmede het informeren van gebruikers over de aanwezigheid en beschikbaarheid van deze beelden;

2 het zich, samen met anderen, inspannen voor een goed beheer van het oorspronkelijk materiaal, voor de beschikbaarstelling van vertoningskopieën en voor actieve conservering en restauratie o.a. door middel van werving van aanvullende fondsen;

3 het zich oriënteren met betrekking tot de ontwikkelingen op het gebied van digitalisering van bewegende beelden;

4 het leveren van een bijdrage aan de opbouw van expertise bij de beherende instellingen.

Deze notitie was voor de Provincie de aanleiding om de subsidie toe te kennen.

Voordat het BFA een aanvang nam met zijn activiteiten werd het te voeren beleid nogmaals tegen het licht gehouden. Een in 1994 gehouden onderzoek ten behoeve van de tweede editie van de Gids voor Historisch Beelden Geluidsmateriaal had duidelijk gemaakt dat weliswaar veertig instellingen en bedrijven in Noord-Brabant een audiovisuele collectie beheerden, maar dat dit in de meeste gevallen niet gepaard ging met een adequaat en verantwoord beheer. ${ }^{2}$ Op een schaal van Io scoorden de veertig Brabantse instellingen op de diverse onderdelen van audiovisuele archivering gemiddeld 3,6. Door zich voornamelijk te richten op het verzamelen van gegevens dreigde nu voor het BFA een weinig aanlokkelijk toekomstbeeld, namelijk een centrale filmdatabank die voornamelijk gegevens zou blijken te bevatten van films die feitelijk niet meer bestonden of, als ze er nog wel waren, niet beschikbaar waren voor hergebruik. 


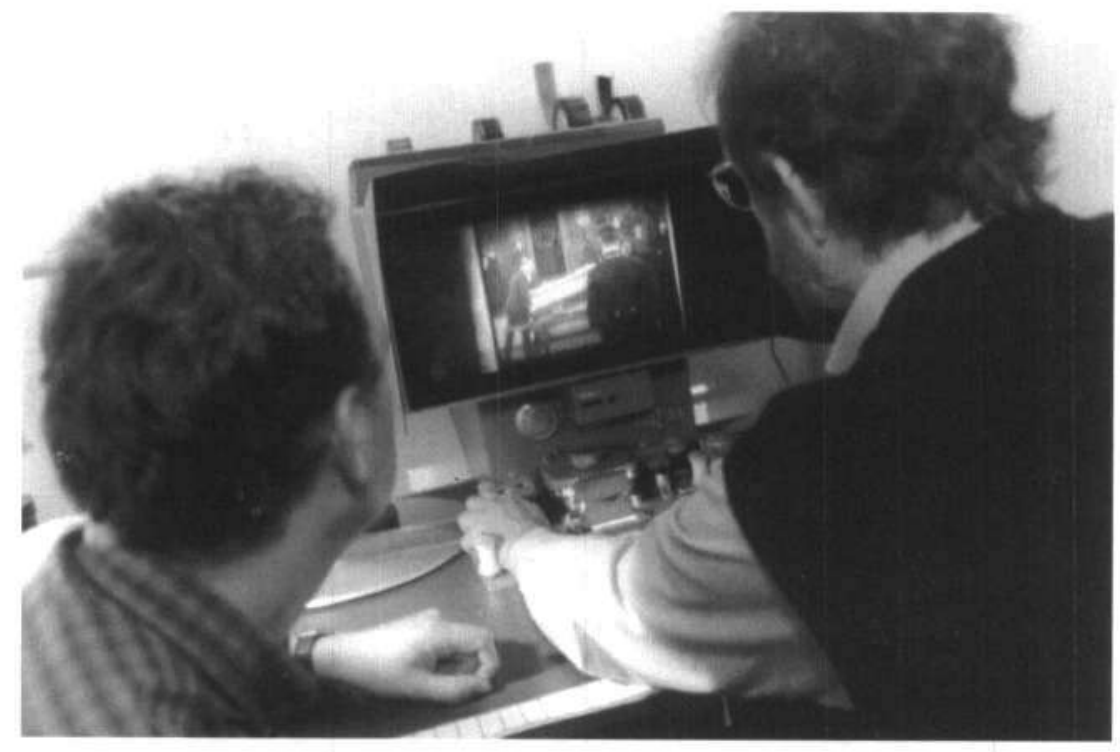

Het viewen van een oude $35 \mathrm{~mm}$ film op een filmmontagetafel Bron: Brabants Film Archief

Niet de opsporing van Brabants filmmateriaal en de bouw van een centrale filmdatabank plus viewingcollectie dienden derhalve op de eerste plaats te komen, maar de opbouw van een structurele beheersvorm in de provincie van het traject van acquisitie, behoud, ontsluiting en beschikbaarstelling van audiovisueel materiaal. De noodzaak hiertoe was des te groter omdat de archiefdiensten, verenigd in de Kring van Archivarissen in NoordBrabant (KAN), er in meerderheid de voorkeur aan hadden gegeven om zelf hun eigen av-collecties te blijven beheren. Het ontwikkelen van een adequate infrastructuur was dus niet alleen een zaak van het BFA maar ook van de KAN en haar leden.

In 1996 trad het BFA toe tot de KAN. Nog in hetzelfde jaar werd op voorstel van het BFA door de Kring een projectgroep ingesteld, speciaal belast met het ontwikkelen van een adequate infrastructuur op het terrein van av-archivering. Een eerste succes boekte de projectgroep toen de KANleden er in het najaar van 1997 mee instemden om via gezamenlijke aanpak tot een aantal wezenlijke voorzieningen op het terrein van av-archivering te komen. Op basis van deze uitkomst deed de projectgroep in 1998 voorstellen voor een centraal filmdepot en een scholingscursus av-archivering voor archiefmedewerkers. Eind 1998 werd het filmdepot van de Gemeentelijke Archiefdienst te Bergen op Zoom aangewezen als centraal filmdepot voor Noord-Brabant. In 1999-2000 werd door de Gemeenschappelijke Opleiding (Go) in Den Haag een op maat gesneden cursus aangeboden aan medewerkers van de Noord-Brabantse archieven. Momenteel is overleg gaande met de Archiefschool voor een cursus 'management van audiovisuele archieven'. 


\section{Website}

Behalve op de ontwikkeling van een adequate infrastructuur heeft het BFA zich ook gericht op het opsporen van Brabants filmmateriaal. Ook werden de particuliere sector, verenigingen, bedrijven en dergelijke bij deze speurtocht betrokken. Om een zo breed mogelijk publiek te informeren over het bestaan van het BFA, werd een groot aantal activiteiten ondernomen. Op de eerste plaats moeten de Drie Historische Dagen vermeld worden, die op 4,5 en 6 oktober 1996 in het Provinciehuis werden gehouden. De vertoning van historische films zowel tijdens het openingsprogramma als in de speciale filmzaal werd een groot succes. De veertig voorstellingen van Cinema Brabantia trokken in drie dagen tijd meer dan tweeduizend bezoekers. Grote groepen belangstellenden konden ook bereikt worden via de publieke regionale televisiezender Omroep Brabant TV. Sinds I september 1997 zijn in het programma CINEMA BRABANTIA wekelijks historische filmbeelden van Noord-Brabant te zien. ${ }^{3}$ Het programma leverde de nodige reacties op, in de vorm van aanmelding van nog onbekend historisch materiaal of verzoek om inlichtingen. Met het oog op dat laatste werd een folder uitgebracht.

Sinds 1998 beschikt het BFA ook over een eigen website: http:// cwis.kub.nl/-dbi/bfa/index.htm). Een onderdeel van deze site is een elektronisch formulier voor het aanmelden van onbekende films. Het BFA kreeg bovendien de beschikking over de videobanden van alle afleveringen van CINEMA BRABANTIA (voor de seizoenen I997-1998 en 1998-1999 ging het om 76 afleveringen) en van de films die hiervoor waren geselecteerd. Deze banden vormen het eerste gedeelte van de beoogde BFAviewing-collectie. Naast de wekelijkse vertoning op Omroep Brabant TV organiseerde het BFA ook zelf een aantal traditionele filmvoorstellingen. Daarbij werd samengewerkt met een of meer plaatselijke organisaties op het terrein van geschiedbeoefening en/of film. Ook hiervoor was veel belangstelling. Zo trokken voorstellingen in Nieuwendijk en Budel elk ruim tweehonderd toeschouwers; in Waalwijk kwamen zelfs achthonderd mensen kijken.

In de zomer van 1998 nam het NAA het initiatief tot de Nationale Inventarisatie Audiovisuele Collecties. Deze landelijke inventarisatie bood het BFA de mogelijkheid opnieuw een groot aantal instellingen en personen in Noord-Brabant te benaderen met het verzoek een enquêteformulier in te vullen omtrent hun audiovisueel bezit. Het ging om instellingen op historisch gebied, uit de gezondheidszorg en het onderwijs en om lokale omroepen. Ongeveer 350 van de ruim zeshonderd aangeschrevenen reageerden. De gegevens zijn niet alleen verwerkt in het verslag over de inventarisatie dat onder titel Horen zien en zwijgen in september 1999 door 
het NAA werd gepubliceerd, maar ook in de derde editie van de reeds genoemde Gids voor historisch beeld-en geluidsmateriaal. ${ }^{4}$ Het BFA wil de grote hoeveelheid ingevulde vragenlijsten benutten om samen met de plaatselijke archiefdiensten het belang van het aangemelde materiaal vast te stellen en tot een adequaat acquisitie- en selectiebeleid te komen.

\section{Elise}

Het BFA wil het filmmateriaal beschikbaar stellen via incidentele filmvertoningen, het CINEMA BRABANTIA-programma op televisie en de viewingcollectie bij het BFA. Daarnaast moet het mogelijk worden het materiaal via internet te raadplegen. De кUв participeert sinds enkele jaren in het Elise-project, waaraan ook universiteiten en musea uit Ierland en Engeland deelnemen. Doel van dit project is om na te gaan welke mogelijkheden internet biedt om niet alleen catalogi en inventarissen beschikbaar te stellen maar ook de bijbehorende documenten.

Het eerste deel van het project, Elise-I, betrof met name stilstaande beelddocumenten. Elise-II heeft betrekking op bewegende beelden. Voor het BFA betekende Elise-II een uitgelezen kans om een deel van het materiaal dat de afgelopen jaren opgespoord en in uitzendingen van CINEMA BRABANTIA vertoond was, te digitaliseren en beschikbaar te stellen via internet. Voordat de filmdatabank op internet kan worden gepresenteerd, moet eerst het BFA-format definitief worden vastgesteld. Daarbij zal rekening worden gehouden met de ervaringen die zijn opgedaan bij het gebruik van het NAA-proefbestand. Verder moeten de reeds bijeengebracht bestanden geconverteerd worden. Tot slot moet het resterende deel van de gegevens handmatig worden ingevoerd. Voor een verdere verdieping van de databank is het BFA aangewezen op de Noord-Brabantse archiefdiensten. Omdat de meeste av-documenten nauwelijks exacte inhoudelijke gegevens bevatten, worden de archieven met hun specifieke kennis en contacten inzake de lokale geschiedenis in staat geacht om de nog niet bekende personen, lokaties en gebeurtenissen op de bewegende beelden te identificeren. Deze lokale gegevens worden vervolgens aan de filmdatabank toegevoegd.

Deze inbreng van de plaatselijke archiefdiensten past in de positie die het BFA ook in de komende jaren wil innemen. Weliswaar wil het een centrale rol blijven spelen bij het opsporen van av-materiaal, het instandhouden van een centrale raadpleegcollectie en een viewingmogelijkheid in de bibliotheek van de кUв, het bijhouden en verder ontwikkelen van een centrale filmdatabank en het verlenen van informatie, kennis en expertise op het terrein van de audiovisuele archivering. Maar de plaatselijke 
archiefdiensten in Noord-Brabant zijn de aangewezen instellingen om de acquisitie, het materieel beheer, de diepgaande ontsluiting, de opbouw van lokale raadpleegcollecties en de kennisvergaring door scholing als primaire en structurele taken op zich te nemen.

\section{Noten}

I J. van Muilekom, 'Vogelvrij in Noord-Brabant', in: Brabantia, februari 1992, p. 2O-2I.

2 M. Lauwers, Gids voor historisch beeld-en geluidsmateriaal, Amsterdam 1994.

3 F. van der Maden, 'Cinema Brabantia, een speurtocht naar Brabants filmmateriaal', in: Archievenblad, augustus 1998, p. 22-23.

4 M. Lauwers, Horen, zien en zwijgen. Conclusies van de Nationale Inventarisatie Audiovisuele Collecties, Hilversum 1999; J. Kooyman, Gids voor historisch beeld-en geluidsmateriaal, Amsterdam 1999. 